NIH on the market

\section{Washington}

THE sales pitch in the hotel ballroom sounded familiar: let us show you "how to put our know-how to work for you". What made the pitch unusual was that the speaker was not an official from a private research organization, but Don Newman, number two man at the Department of Health and Human Services, and what he was selling was the 'know-how' of government researchers at the National Insitutes of Health (NIH) and the Alcohol, Drug Abuse and Mental Health Administration (ADAMHA).

Newman was making his offer at the first ever NIH/ADAMHA-Industry Collaboration Forum, held last month. The forum was a direct consequence of the Federal Technology Transfer Act of 1986 which promotes cooperative arrange ments between industry and federal laboratories. Over a hundred research projects were offered up on posters as potential areas for collaboration, and some 250 representatives of industry were on hand to sift through the collection, looking for projects to fit in with their research plans.

The mechanism NIH hopes will make these collaborations work is the Cooperative Research and Development Agreement. Under these agreements, companies can negotiate for an exclusive licence to any marketable products that come about as a result of a collaboration. Philip Chen, $\mathrm{NIH}$ associate director, says this new mechanism will make it easier for industry to enter into agreements with federal researchers, avoiding much of the red tape that hindered collaborations in the past.

Chen is encouraged by the turnout for the first forum, and expects that these forums will become an annual or possibly semi-annual event. But he agrees with some participants who felt that there are still some problems with the format. Many of the posters were too 'scientific', and did not provide any suggestion of commercial applications for the research, and some complained that there was not sufficient advance notice of what would be on display for companies to bring appropriate experts to evaluate the research.

Newman suggested in his opening address that US competitiveness would be improved if companies would take advantage of research done in federal laboratories. But attending the forum were companies with headquarters in Japan, West Germany, Italy, Canada and the United Kingdom, as well as the United States. Newman explained that as all the foreign companies present have US subsidiaries, they would provide jobs for US workers if they entered into collaborative research projects.

Joseph Palca

\title{
More money is found for UK research councils
}

\section{London}

THE government added $£ 300$ million to the science budget of the research councils last week. Not all of that money will go towards building up the science base, but enough of it to satisfy some of the critics of the government's past record on science spending that a change of attitude towards science is taking place.

The money will be spread over the next three years. Next month The Advisory Board for the Research Councils (ABRC) will advise the government on how it should be distributed. The fear of the research councils will be that a significant proportion of the money may be directed to specific projects desired by the government. such as the Medical Research Council's AIDS research programme. In its advice to the government in July, the ABRC said that about $£ 150$ million would be needed over the three years to support the AIDS programme, the British Antarctic Survey, the British Geological Survey (BGS) and to pay the country's contributions to the European particle physics laboratory, CERN (see Nature 334, 279; 1988). But the government may choose to spend less than $£ 150$ million on these projects. This week it said it would spend only $£ 12$ million on the BGS, compared to the $£ 42$ million called for by the ABRC, and it is still looking for ways to reduce its contribution to CERN, which the ABRC says will require $£ 27$ million over the next three years.

Even assuming these projects were funded in full, the research councils will have an extra $£ 50$ million to distribute annually. But the ABRC had asked for significantly more. It said that $£ 379$ million was needed for the councils alone, and that money earmarked for specific projects should be provided separately. Of the money it wanted for the councils, about half would not be supporting research, but would be spent on restructuring the councils to make them more efficient and effective.

But Sir David Philips, chairman of the ABRC, said he was happy with the money awarded. It would provide sufficient extra money for many of the scientific initiatives proposed by the ABRC and would enable a start to be made on implementing an effective strategy for the future development of the science base, he said. The board is likely to direct a significant amount of the money to setting up interdisciplinary research centres to which it gives high priority. To set up 30 such centres over the next three years would require $£ 105$ million.

The extra $£ 95$ million which will go on the science budget for 1989-90 brings the total spending to $£ 825$ million, an increase of 16 per cent over the figure for 1988-89. Jeremy Bray, Labour Party spokesman for science and technology points out though that if earmarked money is subtracted, the increase amounts to only 3 per cent. Denis Noble of the pressure group, Save British Science, says that this is the first time the government has planned a real increase in funds for science; it marks a change in mood within the government and marks a victory for the science lobby. Also announced last week was $£ 14$ million to be spent immediately by the research councils and the universities on equipment for basic science. The committees reviewing provision of chemistry and physics in universities had each asked for $£ 36$ million urgently.

Pressure is not off the universities to find funding from other sources. They have been awarded an extra $£ 100$ million over three years, meaning a period of level funding. The new Universities Funding Council will distribute $£ 1,672$ million in 1989-90.

Christine McGourty

\section{Soviet criticism of}

\section{Hungarian dam \\ Budapest/Bratislava}

A LEADING Soviet economist has sharply criticized Hungary's plans to divert the river Danube and build a massive hydroelectric plant at Nagymaros. Speaking at a floating conference on board $\mathrm{M} / \mathrm{V}$ Rousse, Academician Boris Laskorin criticised the Hungarian government's view that the project is now too expensive to stop. $\mathrm{He}$ argued that the long-term impact of the dam on the environment will have economic consequences that have been ignored.

M/V Rousse made its way along the Danube from Rousse in Bulgaria to Passau in West Germany carrying participants in 'Ecodanube-88', a conference on the future of the entire Danube basin. The sponsor is 'Ecoforum for Peace', a non-governmental organization set up in 1986 to unite scientists from East and West around ecological problems on an interdisciplinary basis.

The greatest concern over the environmental consequences of the Nagymaros plant and a sister plant at Gabcikovo in Slovakia was expressed by Viktor Romanenko of the Ukrainian Academy of Sciences, who earlier this year led an expedition monitoring Danube pollution. Although he was careful not to attack the project directly, he stressed that newlyavailable data from Soviet rivers show that large dams on rivers in flat terrain are damaging and unlikely to meet their costs in electrical output. 